\title{
MULTI-SCALE ORGANIZATION OF WATER VAPOR OVER LOW AND MID-TROPICAL AFRICA
}

\author{
ONDEGO JOEL BOTAI* \\ Department of Geography, Geoinformatics and Meteorology, University of Pretoria, \\ Pretoria, 0002, South Africa (joel.botai@up.ac.za) \\ VENKATARAMAN SIVAKUMAR \\ National Laser Centre, Council for Scientific and Industrial Research, P.O. Box-395, \\ Pretoria, South Africa \\ Department of Geography, Geoinformatics and Meteorology, University of Pretoria, \\ Pretoria, 0002, South Africa \\ WILLEM LUDWIG COMBRINCK \\ Hartebeesthoek Radio Astronomy Observatory, P.O. Box 443, 1740, Krugersdorp, \\ South Africa \\ Department of Geography, Geoinformatics and Meteorology, University of Pretoria \\ Lynnwood Road, 0002, South Africa \\ CORNELIS JOHANNES DE WET RAUTENBACH \\ Department of Geography, Geoinformatics and Meteorology, University of Pretoria, \\ Pretoria, 0002, South Africa

\begin{abstract}
In this study, data from the Southern Hemisphere ADditional OZonesondes (SHADOZ) are used to compute the spatially averaged water vapor $\left(\mathrm{WV}_{\mathrm{g}}\right)$ over low and mid-tropical Africa. Based on the SHADOZ stations, reanalysis data from the National Centres for Environmental Prediction and Atmospheric Research (NCEP/NCAR) were partitioned into four grid cells: (1) over Ascension $\left[10.0^{\circ} \mathrm{S}\right.$ to $7.5^{\circ} \mathrm{S}, 12.5^{\circ} \mathrm{W}$ to $15.0^{\circ} \mathrm{W}$ ]; (2) Nairobi $\left[0.0^{\circ} \mathrm{N}\right.$ to $2.5^{\circ} \mathrm{S}, 35.0^{\circ} \mathrm{E}$ to $37.5^{\circ} \mathrm{E}$ ]; (3) Irene [27.5 ${ }^{\circ} \mathrm{S}$ to $25.0^{\circ} \mathrm{S}, 27.5^{\circ} \mathrm{E}$ to $\left.30.0^{\circ} \mathrm{E}\right]$ and (4) Reunion $\left[22.5^{\circ} \mathrm{S}\right.$ to $20.0^{\circ} \mathrm{S}, 55.0^{\circ} \mathrm{E}$ to $\left.57.5^{\circ} \mathrm{E}\right]$. The mean Water Vapor $(\mathrm{WV})$ was computed over these grid cells to obtain $\left(\mathrm{WV}_{\mathrm{g}}\right)$. The temporal scales of WVg fluctuations have been analyzed using wavelet transforms and Principal Components. Analysis (PCA) of the $\mathrm{WV}_{\mathrm{g}}$ wavelet-transformed coefficients was used to demonstrate spatial organization of WV. The results indicate that WV exhibits localized spatial coherence patterns. Further, the analysis show strong seasonal dependence of WV which is associated with global and local atmospheric circulation.
\end{abstract}




\section{Introduction}

Generally, Water Vapor (WV) plays a key role in both the radiative and dynamic processes of the climate system (Zveryaev et al., 2007). It is a major greenhouse gas which predominantly absorbs the Earth's outgoing thermal energy while, part of this energy re-radiates back to the surface. It is the most variable atmospheric constituent (Bevis et al., 1992; Sun and Lindzen, 1993) which has applications in both short-term Numerical Weather Prediction (NWP) (Cucurell et al., 2000) and in Earth's climate changes and hydrological cycles (Johnsen, 2003). Global distribution and variability of atmospheric WV has also been documented in the literature (see Dai, 2006) and there is also documented literature on WV variability over regional scales (e.g. Trenberth et al., 2005).

A number of ground based and space-borne remote sensors are available that measure vertical and horizontal profiles of water vapour: e.g. radiosondes, light detection and Ranging (LiDAR-Raman), Global Navigation Satellite Systems (GNSS) receivers, Very Long Baseline Interferometry (VLBI) and Water Vapor Radiometers (WVR) (Raschke, 2002). One important consideration in WV analysis is to show how the WV fluctuations are organized into diurnal, synoptic, seasonal and climatic categories and if WV variability is associated with spatial structure and dominant modes of the rotated Principal Component Analysis (PCA) of the WV energy spectra. The rotated PCA component of WV would capture the dominant modes of the WV in temporal scales with similar spatial organization (Petr, 2005). This linear transformation of PCA allows for easy interpretation of the strongest spatial relationships of $\mathrm{WV}$ features that drive atmospheric weather systems, such as clouds, over a particular region. Although, the global spatial distribution and trends in WV are dominated by large-scale dynamics, such as the El Nino-Southern Oscillation (ENSO) rather than the thermodynamics, (see., Zveryaev and Allan, 2005), the linkage between WV anomalies and atmospheric circulation processes is difficult to establish due to the complexity of the spatial-temporal structures of WV. The spatial and temporal variability of WV in the mid and low-tropical Africa ranges from a few kilometers to thousands of kilometers, and from a few minutes to several days, similar to meso or synoptic-scale processes, respectively (Husak, 2005). Therefore, analyses of correlations of WV between the spatial grids are of great practical importance for a better understanding of the background processes that lead to the development of hazardous weather systems (for example floods, thunderstorms, tropical cyclones).

In order to understand the feedback processes in mid and low-tropical Africa, a robust methodology of examining the spatial-temporal structure of $\mathrm{WV}$ is required. In this study, the spatial and temporal organization of $\mathrm{WV}$ is analyzed simultaneously using orthogonal wavelet transform which allows for calculating the total energy of $\mathrm{WV}$ by accumulating individual scales of the spatial or 
temporal scale. Results obtained would form the basis for future comprehensive analysis to establish the relation between WV variability and the associated atmospheric weather systems, as well as any other forcing mechanisms observed in low and mid-tropical Africa.

\section{Data and Methodology}

The main data source used in this study is about 8-years of upper air radiosonde/ozonesonde data archived at the Southern Hemisphere ADditional OZonesondes (SHADOZ) station network of four stations: Ascension, Irene, Reunion and Nairobi (see Thompson et al., 2003 for further details about the SHADOZ network). The geographical locations of the SHADOZ stations and details about data periods considered in this paper are tabulated in Table 1.

Table 1. SHADOZ stations used in the current study and the time period considered for analyses.

\begin{tabular}{|c|c|c|c|c|c|}
\hline Station & $\begin{array}{c}\text { Longitude } \\
{\left[{ }^{\mathbf{0}}\right]}\end{array}$ & $\begin{array}{c}\text { Latitude } \\
{\left[{ }^{\mathbf{0}}\right]}\end{array}$ & $\begin{array}{c}\text { Elevation } \\
{[\mathbf{m}]}\end{array}$ & $\begin{array}{c}\text { Launch } \\
{[\mathbf{N o}]}\end{array}$ & $\begin{array}{c}\text { Time } \\
\text { Period }\end{array}$ \\
\hline Nairobi & $36.80 \mathrm{E}$ & $1.27 \mathrm{~S}$ & 1795.00 & 370 & $\begin{array}{c}\text { Jan } 1998 \\
\text { to Aug } \\
2007\end{array}$ \\
\hline Reunion & $55.48 \mathrm{E}$ & $21.06 \mathrm{~S}$ & 24.00 & 293 & $\begin{array}{c}\text { Jan } 1998 \\
\text { to Oct } \\
2006\end{array}$ \\
\hline Irene & $28.22 \mathrm{E}$ & $25.90 \mathrm{~S}$ & 15.24 & 232 & $\begin{array}{c}\text { Nov } 1998 \\
\text { to Dec } \\
2006\end{array}$ \\
\hline Ascension & $14.42 \mathrm{~W}$ & $7.98 \mathrm{~S}$ & 91.00 & 397 & $\begin{array}{c}\text { Jan } 1998 \\
\text { to Dec } \\
2006\end{array}$ \\
\hline
\end{tabular}

The SHADOZ stations were configured in order to obtain spatially averaged $\mathrm{WV}$ values $\left(\mathrm{WV}_{\mathrm{g}}\right)$ over four grid boxes and time series from reanalysis data of the National Centres for Environmental Prediction and Atmospheric Research (NCEP/NCAR) (Kalnay et al., 1996). Time series of integrated WV (hereafter, $\mathrm{WV}_{\text {ncep }}$ ) was constructed from the average of the closest four NCEP/NCAR reanalysis data grid points at each one of the SHADOZ stations (see, figure 1) using NCEP/NCAR reanalysis data. Take note that the NCEP/NCAR reanalysis data have a latitude and longitude resolution of $2.5^{\circ}$. 


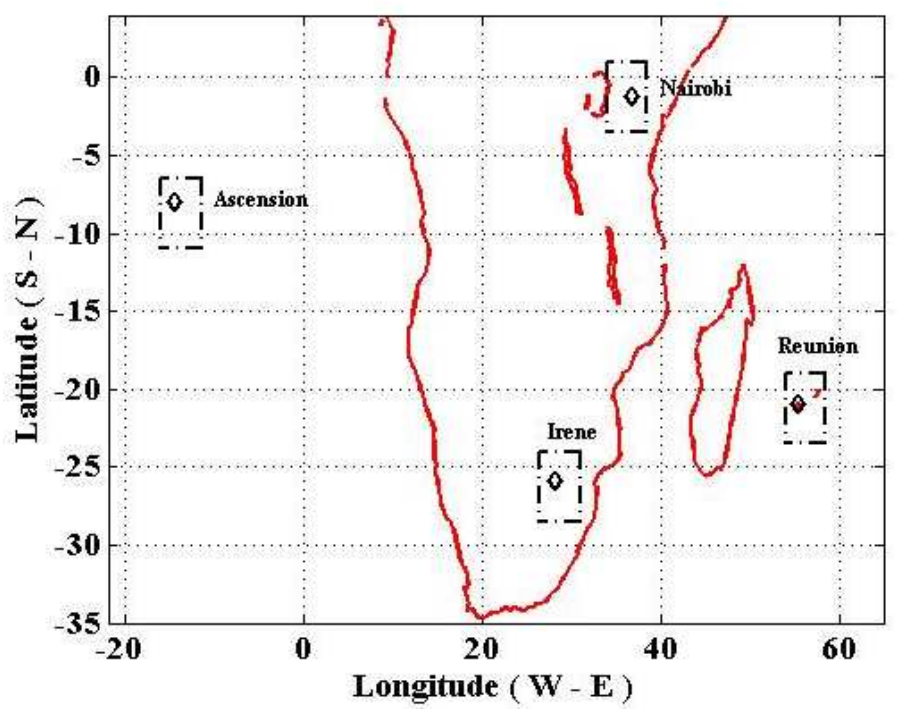

Figure-1: The SHADOZ stations with the corresponding grid boxes formed by the closest four grid points of reanalysis data from the National Centers for Environmental Prediction and Atmospheric Research (NCEP/NCAR).

For each NCEP/NCAR grid point, the temporal series of $\mathrm{WV}_{\mathrm{g}}$ is tested manually for inherent normal distribution and then transformed into Box-Cox (Box and Cox, 1964) which ensures a normal distribution. Prior to the Box-Cox transformation, the data have been detrended. Further, in order to account for latitudinal distortions, each point of $\mathrm{WV}_{\mathrm{g}}$ anomalies was weighted by the square root of the cosine of latitude (North et al., 1982). The resulting time series has been linearly detrended and subjected to non-decimal Haar wavelet (Lindsay et al., 1996) transform to capture localized temporal fluctuations.

Comparable to the Fourier Transform (FT), the wavelet power spectrum (absolute value squared of the wavelet transform) provides the total energy of the $\mathrm{WV}_{\mathrm{g}}$ time series at a given scale. FT gives information about what frequencies are present in the signal, but lacks the ability to correlate the frequencies with the time of their presence. In general, the difference between Fourier and wavelet coefficients is that the former is influenced by a function on its entire domain (global measure), while the latter is influenced by local features. The wavelet power spectrum is therefore chosen in this paper as a better measure of variance attributed to localized events.

The wavelet coefficients at each time scale were used to compute the energy spectrum per spatial scale to form a temporal scale series (S) over the grid points 
(G): i.e., a matrix D with dimensions of $\mathrm{S} \times \mathrm{G}$.

\section{Results}

A daily vertically integrated $\mathrm{WV}_{\mathrm{g}}$ time series in mid and low-tropical Africa is computed from the SHADOZ network points and from gridded NCEP/NCAR reanalysis data that extent over a period of 8-years. The SHADOZ point data were integrated over the height column from $2 \mathrm{~km}$ to $13 \mathrm{~km}$ and whereas, the NCEP/NCAR water vapor data integrated between the $700 \mathrm{hPa}$ and $200 \mathrm{hPa}$ pressure levels. The upper and lower limits chosen were respectively based on the sensitivity of the balloon-borne measurements and mean-sea level of the SHADOZ stations. In order to compare the corresponding WV measurements from NCEP/NCAR reanalysis data, corresponding SHADOZ dates are considered. The NCEP/NCAR reanalysis data are available four times a day (every six hours) and the daily mean was computed for comparison with SHADOZ observations which occur once a day.

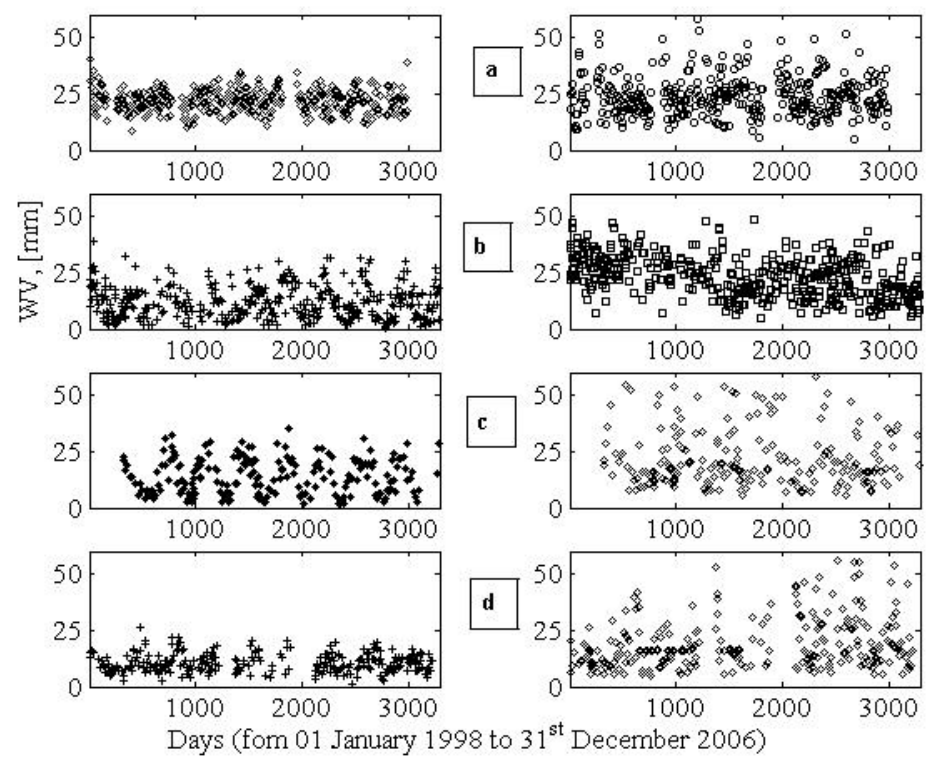

Figure 2: Daily integrated spatially averaged Water Vapor $\left(\mathrm{WV}_{\mathrm{g}}\right)$ in $\mathrm{mm}$, calculated from four SHADOZ stations (right) and the gridded NCEP/NCAR reanalysis data (left) in the lower- and mid-tropical Africa region over the 8-year period 1998 to 2007 for the SHADOZ stations (a) Nairobi (b) Ascension (c) Irene and (d) Reunion.

The calculated $\mathrm{WV}_{\mathrm{g}}$ values from radiosonde measurements at the SHADOZ 
stations and from the NCEP/NCAR reanalysis data are plotted in figure 2. It is clear from the figure that the NCEP/NCAR reanalysis data exhibit a cyclic trend over the period of observations, whereas such cycles are not evident in the SHADOZ observations. The difference might be due to the coarse latitude and longitude resolution of NCEP/NCAR data that were averaged over the station grid box, while each SHADOZ station corresponds to a particular location. In addition, sensitivity of the balloon measurements may have contributed to the differences in $\mathrm{WV}_{\mathrm{g}}$ from the two measurements. Further to this NCEP/NCAR reanalysis data are based upon simulation with possible inherent biases. The differences between the NCEP/NCAR reanalysis data and SHADOZ station data were calculated for each station. Results concluded that the Irene and Reunion stations have higher mean deviations $(\sim 40 \mathrm{~mm})$ while the Nairobi and Ascension stations show a mean $\mathrm{WV}_{\mathrm{g}}$ deviation of $\sim 30 \mathrm{~mm}$ (figures are not shown).

It is understandable from figure 2 that $\mathrm{WV}_{\mathrm{g}}$ fluctuations are difficult to discern from the time series. The excursions from the mean denote the presence of exogenous processes that play a significant role in $\mathrm{WV}_{\mathrm{g}}$ fluctuations. These stochastic processes are manifestations of local weather system processes (eg., convection, precipitations etc.). In order to better understand these fluctuations, the nature of distribution needs to be known. The standard probability distributions of $\mathrm{WV}_{\mathrm{g}}$ are used and are compared to the normal Guassian distribution. The normal Guassian distribution has been generated by selecting random data sets. In order to assess the normal (Gaussian) distributions of $\mathrm{WV}_{\mathrm{g}}$, the Quartile-Quartile (QQ-plot were drawn between the Guassian generated and the probability distribution of $\mathrm{WV}_{\mathrm{g}}$ ). A linear variation in the QQ plot could signify a normally distributed time series. The distribution has been tested, individually for each station (figure 3). The regression co-efficients obtained illustrate that the SHADOZ station Ascension has high linearity in comparison to that of Nairobi, Irene and Reunion. A maximum non-linear fluctuation component of $\sim 10 \%$ was obtained for Reunion. On the other hand, Irene, Nairobi and Ascension have values of $\sim 8 \%, 5 \%$ and $1 \%$, respectively. It implies that Ascension results follow a normal distribution and appear not to be affected by non-linear local weather conditions. 


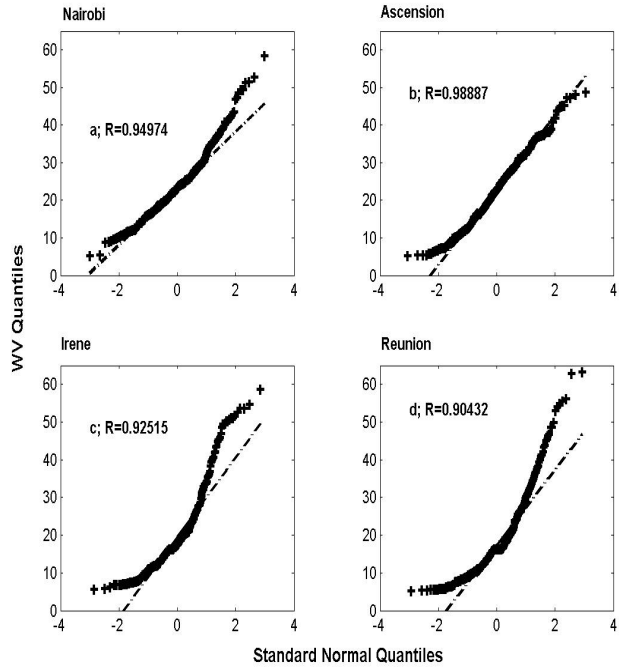

Figure 3: Quartile-quartile (QQ) plot of a Gaussian distribution, and the probability distribution of $\mathrm{WV}_{\mathrm{g}}$ at the four SHADOZ stations under consideration.

In order to study the local temporal fluctuations of $\mathrm{WV}$, the Haar wavelet transform of Maximum overlap discrete technique has been applied. The wavelet coefficients derived from the wavelet transform capture local fluctuations in time series in both time and frequency. Each SHADOZ station's data were grouped in terms of month and year, following by the calculation of the corresponding mean. The corresponding monthly mean over the 8-years period of data is subjected to the wavelet transform after performing de-trending. Figure 4 depicts the obtained wavelet co-efficient (amplitude) at different temporal scales of 3,8,12 and 36 months (from bottom to top) or the time period of oscillation of $\mathrm{WV}_{\mathrm{g}}$ at a given location. The relation between period of oscillation of $\mathrm{WV}_{\mathrm{g}}$ fluctuations and the wavelet scale index is based on the relation $s=2^{\mathrm{j}-1}$, where the $\mathrm{j}^{\text {th }}$ index denotes the period. The method of deducing the wavelet co-efficient is documented in Percival and Walden (2000). Although, scale-1 ( 3 month) does not offer any clear information on the fluctuations, other higher order scales show a significant oscillation at all the stations. Notably, the annual oscillation (scale-3) is clearly distinguishable at all the stations. If compared to the other stations, Nairobi exhibits a clear cyclic variation. For almost all the stations, the scale-4 (3-year) component does not complete one period of a cycle, inferring that the periodicity is more than 12years. It is noted here that the maximum possible number of scales obtained depends on the length of data period used. The log-log plot of the wavelet energy (not shown here) reveal an approximate power law scaling at lower time scales, which breaks down at high time scales. These results are consistent with those of Lay (1997). At high time scales, the break down in the linear 
relationship is associated with response of $\mathrm{WV}_{\mathrm{g}}$ fluctuations to tele-connection patterns such as the influence of ENSO in the low and mid- tropical Africa, see for example Trenberth et al., (2005).

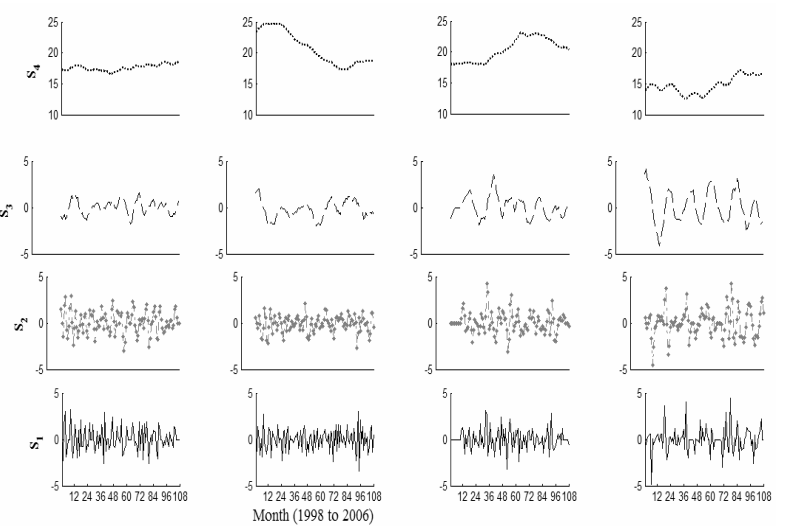

Figure 4: Haar wavelet spectra at different scales $(n=1,2,3,4)$ and at different station locations (Ascension, Reunion, Irene and Nairobi) - from left to right, respectivily. See Table 1 for the corresponding geographic coordinates.

PCA has been determined for the wavelet coefficients of all the four stations, and the calculated variance is presented in figure 5. The first three variance components account for $98 \%$ of the $\mathrm{WV}_{\mathrm{g}}$ variations. The first component represents high frequency temporal fluctuations (monthly time scales), and accounts for $67 \%$ of the variability. Component two represents the variance associated with annual fluctuations, and accounts for about $27 \%$ of the $\mathrm{WV}_{\mathrm{g}}$ fluctuations. About $4 \%$ of $\mathrm{WV}_{\mathrm{g}}$ variability is associated with low frequency fluctuations $(1<$ timescales $<9$-year $)$. Decadal fluctuations cannot be inferred convincingly due to the short time-span of the data (8-years: 1998 to 2006. These results show that there is a distinct spatial structure for each short term temporal $\mathrm{WV}_{\mathrm{g}}$ variation in the low and mid-tropical Africa region that could be attributed to synoptic/seasonal-scale weather systems, which is consistent with findings from Husak (2005) who reported that seasonal weather systems, topography, the Inter-tropical Convergence Zone (ITCZ) and monsoon winds affect WV distribution and fluctuation. Jin et al. (2008) also reported that the variability of water vapor in China is dominated by seasonal variations. In addition, the spatial distribution of WV dependence on the thermodynamic relationship between $\mathrm{WV}$ and temperature has been reported in Zveryaev and Allan, 2005. The marked differences between WV fluctuations at longer timescales could be attributed to the $\mathrm{WV}$ response to tele-connection patterns such as ENSO in the low and mid-tropical Africa, which is in line with the findings of Trenberth et al. (2005) who had indicated that the variability of WV 


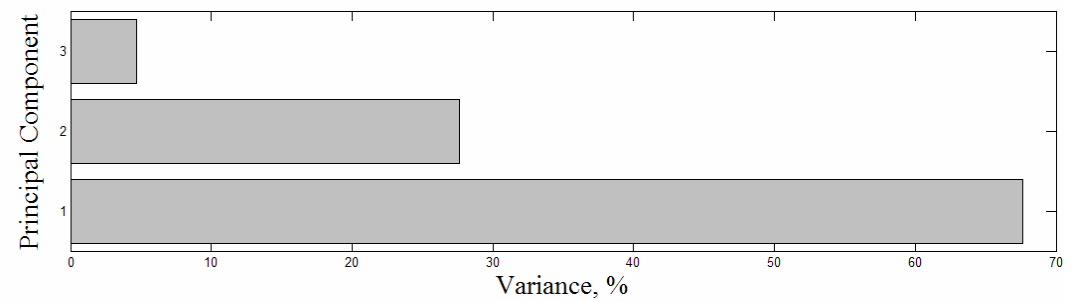

Figure 5: Co-variance of the Principle Component Analysis (PCA) components obtained from the four stations under consideration.

is dominated by the evolution of ENSO. This link shows a strong relationship over the oceans between WV and Sea Surface Temperatures (SSTs). Further, the African low and mid- latitude WV has a strong link to rainfall due to its close association with the mean wind flow, and convergence of moisture by trade winds as well as the links to SSTs. In addition, the correlation analyses performed between surface temperature and WV shows that there exists a link between $\mathrm{WV}$ anomalies to regional air temperature variations with marked seasonal dependence (the results are not shown here) over all four SHADOZ stations.

\section{Concluding Remarks}

In an effort to analyze regional spatial and temporal features of WV variability over low and mid-tropical Africa, NCEP/NCAR reanalysis data around the SHADOZ network of four stations were used to calculate spatially averaged WV (refer to $\mathrm{VW}_{\mathrm{g}}$ ) over the period 1998 to $2006 . \mathrm{WV}_{\mathrm{g}}$ was calculated as spatial average of the four closest NCEP/NCAR grid points around the SHADOZ stations to form grid cells. Based on these grid cells, data from NCEP/NCAR reanalysis data were also used to calculate the vertically integrated column of $\mathrm{WV}$ over the same time epoch for comparison. For the first time, the $\mathrm{WV}_{\mathrm{g}}$ variability in the low and mid-tropical Africa were analyzed using point data from the SHADOZ network indicating high frequency fluctuations in the wavelet space. Common to the entire SHADOZ network considered in this study is the pattern of temporal $\mathrm{WV}_{\mathrm{g}}$ fluctuations with monthly time scales dominating. This dominant variance appears to be associated with locally driven WV variations such as the local weather systems. Our results show the power law scaling in the wavelet energy. The approximate log-log linear relationship at smaller temporal scales that breaks down at synoptic scales suggests that the energies at $\mathrm{WV}_{\mathrm{g}}$ on different temporal scales are closely related. In addition, from the PCA, three dominant modes emerge that explains $\sim 98 \%$ of the total spatial variance of the normalized energy. To validate the current findings, future studies will involve the use of observations such as HALOE (ref., Russell et al., 1993), ECMWF 
(ref., Bock et al., 2007) and regional numerical simulation model data sets to determine the temporal and spatial organization of PWV data at finer spatial and temporal scales.

\section{References}

1. Bevis M., Businger S., Herring T. A., Rocken C., Anthes R. A. and Ware R. H., 1992. GPS meteorology: Remote sensing of the atmospheric water vapor using the global positioning system, J. Geoph. Res., 97(D14) pp. 15787-15801

2. Box G. E. and Cox D. R., 1964. An analysis of transformed data, J. Roy. Statist. Soc. B., pp. 211-252

3. Bock O., Bouin M. -N., Walpersdorf A., Lafore J. P., Janicot S., Guichard F. and Agusti-Panareda A., 2007. Comparison of groundbased GPS Precipitable water vapor to independent observations and NWP model reanalyses over Africa, Q. J. R. meteorol. Soc. 133, pp. 2011-2027

4. Cucurull L., Navascues B., Ruffin G., Elosegui P., Rius A. and Vila J., 2000. The Use of GPS to validate NWP systems: The HIRLAM Model, J. Atmos. and Oceanic Technology, 17, pp. 773-777

5. Dai A., 2006. Recent climatology, variability of and trends in global surface humidity. J. Climate 19, pp. 3589-3606

6. Husak G. J., 2005. Methods for statistical evaluation of african precipitation, $P h D$ thesis, University of California, Santa Barbara

7. Jin S., Li Z. and Cho J., 2008. Integrated water vapor field and multiscale variations over China from GPS measurements. J. appl., Meteo., Climatol., 47, pp. 3008-3015

8. Johnsen K. P., 2003. GPS atmosphere sounding project- An innovative approach for the recovery of atmospheric parameters, GKSSForschungzentrum Geesthacht, Geesthacht.

9. Kalkany E., Kanmistu, M., Kistler, R., Collins, W., Deaven, D., Gandin, L., Iredell, M., Saha, S., White, G., Woollen, J., Zhu, Y., Leetmaa, A., Reynolds, B., Chelliah, M., Ebisuzaki, W., Higgins, W., Janowiak, J., Mo, K., Ropelewski, C., Wang, J., Jenne, R. and Joseph, D. 1996: The NCEP/NCAR 40- year reanalysis project, Bull. Amer. Meteor. Soc., 77, pp. 437-471

10. Lay O. P., 1997. The temporal power spectrum of atmospheric fluctuations due to water vapor, Atron. Astrophysics. Suppl. Ser, 122, pp. 535-545

11. Lindsay R. W., Percival D. B. and Rothrock D. A., 1996. The discrete wavelet transform and the scale analysis of the surface properties of sea ice. IEEE Trans. on Geo. and Rem. Sen., 34(3), pp. 771-787.

12. North G., Bell T. L. and Calahan R. F., 1982. Sampling errors in the estimation of empirical orthogonal functions. Man. Wea. Rev. 110, pp. 
699-706

13. Percival D. B. and Walden A. T., 2000. Wavelet methods for time series analysis. Cambridge University Press, Cambridge

14. Petr P., 2005. Water quality assessment using SVD-based principal component analysis of hydrological data. Water SA, 31(4), pp. 417422

15. Raschke E., 2002. Water vapor in the atmosphere. Technical report work package HCP of the CM-SAF, 3001393- RIN, Deutscher Wetterdienst, Offenbach, Germany

16. Russell J. M. III., Gordley L. L., Park J. H., Drayson S. R., Hesketh D. H., Cicerone R. J., Tuck A. F., Frederick J. E., Harries J. E. and Crutzen P. J., 1993. The Halogen Occultation Experiment, J. Geophys. Res., 98(D6), pp. 10777-10797

17. Sun D. and Lindzen R. S., 1993. Distribution of tropical Tropospheric water vapor, AMS. 50(12), pp. 1643-1660

18. Trenberth K. E., Fasullo J. and Smith L., 2005. Trends and variability in column-integrated atmospheric water vapor, Climate Dynamics, 24, pp. 741-758

19. Thompson A.M., Witte J.C., Oltmans S.J., Schmidlin F.J., Logan J.A., Fujiwara M., Kirchhoff V.W.J.H., Posny F., Coetzee G.J.R., Hoegger B., Kawakami S., Ogawa T., Fortuin J.P.F. and Kelder H.M. (2003). Southern Hemisphere Additional Ozonesondes (SHADOZ) 1998-2000 tropical ozone climatology 2. Tropospheric variability and the zonal wave-one,J.Geophys. Res.,108(D2),8241,DOI: 10.1029/2002JD002241

20. Zveryaev I. I. and Allan R. P., 2005. Water vapor variability and in the tropics and its links to dynamics and precipitation. J. Geophys. Res. 110, D21112. DOI: 10.1029/2005JD006033

21. Zveryaev I. I., Wibig J. and Allan R. P., 2007. Contrasting interannual variability of atmospheric moisture over Europe during cold and warm seasons. Tellus, 60A, pp. 32-41, DOI:10.1111/j.1600-0870.2007.00283 